\section{Default neural induction: neuralization of dissociated Xenopus cells is mediated by Ras/MAPK activation}

\author{
Hiroki Kuroda, ${ }^{1}$ Luis Fuentealba, Atsushi Ikeda, \\ Bruno Reversade, and E.M. De Robertis ${ }^{2}$ \\ Howard Hughes Medical Institute and Department \\ of Biological Chemistry, University of California, \\ Los Angeles, California 90095-1662, USA
}

Xenopus embryonic ectodermal cells dissociated for three or more hours differentiate into neural tissue instead of adopting their normal epidermal fate. This default type of neural induction occurs in the absence of Spemann's organizer signals and is thought to be caused by the dilution of endogenous BMPs into the culture medium. Unexpectedly, we observed that BMP ligands continue to signal in dissociated cells. Instead, cell dissociation induces a sustained activation of the Ras/ MAPK pathway, which causes the phosphorylation of Smad1 at sites that inhibit the activity of this transcription factor. It is this activation of Ras/MAPK that is required for neuralization in dissociated ectoderm.

Supplemental material is available at http://www.genesdev.org.

Received February 15, 2005; revised version accepted March 24, 2005.

Neural induction in amphibians requires secreted signals, in particular BMP antagonists, produced in the dorsal organizer region of the embryo (Spemann 1938; Harland 2000; De Robertis and Kuroda 2004). However, early work also showed that brain tissue could be obtained in the absence of the organizer, for example, by simply culturing newt ectodermal explants in sub-optimal saline solutions (Barth 1941; Holtfreter 1944). In Xenopus, neural differentiation without the organizer can be induced by dissociating ectodermal cells, which would otherwise give rise to epidermis, for $3 \mathrm{~h}$ or more (Grunz and Tacke 1989; Sato and Sargent 1989). Addition of Bone Morphogenetic Protein 4 (BMP4) to dispersed Xenopus cells can restore epidermal differentiation (Wilson and HemmatiBrivanlou 1995), leading to the generally accepted proposal that during cell dissociation endogenous BMPs diffuse into the culture medium (Muñoz-Sanjuán and Brivanlou 2002). In this view, the dilution of BMP protein would be the cause of neural differentiation in dissociated cells.

A large body of work also indicates that neural differentiation in vertebrate embryos can be induced by posi-

[Keywords: Neural induction; Smad1; MAPK; FGF; IGF; BMP]

${ }^{1}$ Present address: Shizuoka University, Faculty of Education (Biology), 836 Ohya, Shizuoka, 422-8529 Japan.

${ }^{2}$ Corresponding author.

E-MAIL ederobertis@mednet.ucla.edu; FAX (310) 206-2008.

Article and publication are at http://www.genesdev.org/cgi/doi/10.1101/ gad.1306605 tive signals that act through Receptor Tyrosine kinases (RTKs). Growth factors that signal via RTKs, such as Fibroblast Growth Factor (FGF), Insulin-like Growth Factor (IGF), and Hepatocyte Growth Factor (HGF), are potent neural inducers in vertebrates (Wilson and Edlund 2001; De Robertis and Kuroda 2004; Stern 2004). RTK signaling activates the mitogen-activated protein kinase (MAPK) known as extracellular signal-regulated protein kinase (ERK) via the Ras pathway, and in this way causes neural induction.

Two disparate views dominate the neural induction field at present. Work in the chick embryo has stressed the importance of FGF signaling, whereas work in Xenopus has tended to emphasize the requirement for antiBMPs in neural induction (Harland 2000; Stern 2004). We have argued that these apparently conflicting observations can be reconciled through a molecular mechanism in which Ras/MAPK phosphorylation regulates the BMP transducers Smad1/5/8 (De Robertis and Kuroda 2004). It has been reported that both FGF and IGF can promote neural induction through the phosphorylation, via MAPK, of inhibitory sites located in the linker region of the Smad1 transcription factor (Pera et al. 2003). Linker phosphorylation of BMP-sensitive Smads by MAPK opposes the effect of C-terminal Smad phosphorylation by the BMP receptor serine-threonine protein kinase (Fig. 1A), causing inhibition of the nuclear function of Smad1 and promoting neural development (low BMP/Smad) at the expense of epidermal (high BMP/ Smad) fates (Massagué 2003).

It is known that activation of ERK can be triggered by a large number of external stimuli, including cell stress (Wetzker and Böhmer 2003). In Xenopus embryos, the simple extirpation of ectodermal explants can activate ERK, causing this kinase to become diphosphorylated (dpERK) (LaBonne and Whitman 1997; Christen and Slack 1999). However, this ERK activation by microsurgery is transient, lasting <30 min. Transient ERK activation after animal cap dissection is without phenotypic effect, and the explants go on to differentiate according to their normal epidermal fate. Since BMP and MAPK signaling are integrated during neural induction, we decided to investigate whether cell dissociation in conditions that cause neural differentiation might induce a stronger, or more prolonged, activation of the Ras/MAPK pathway.

In the present paper we report two findings: first, that, unexpectedly, endogenous BMPs continue to signal in an autocrine fashion in dissociated animal cap ectodermal cells, at the same levels as in undissociated cells; second, that default neural differentiation is mediated by a sustained activation of the Ras/MAPK pathway induced by cell dissociation. The results indicate that the choice between epidermal and neural cell fates is determined by the integration of the opposing activities of BMP receptor and Ras/MAPK at the level of Smad1 phosphorylation.

\section{Results and Discussion}

BMPs continue to signal in dissociated cells

Cells from Xenopus animal cap explants develop as epidermis when cultured in saline solution, but when cells 


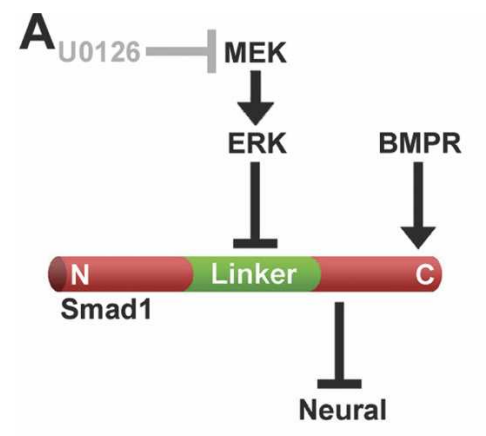

B

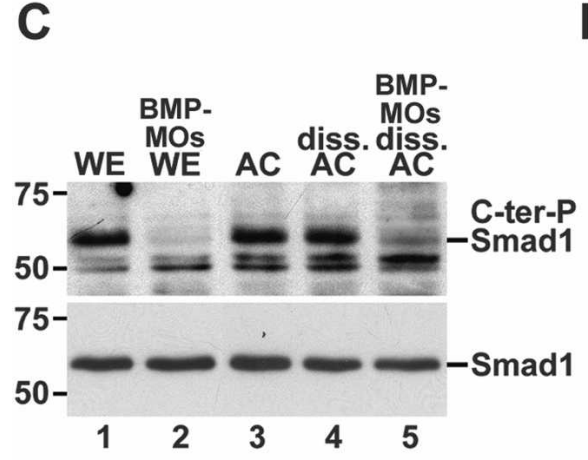

D

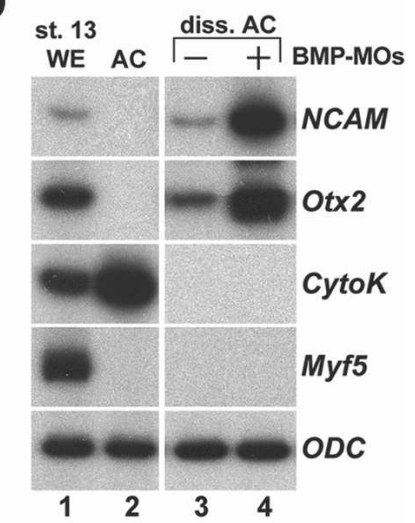

E
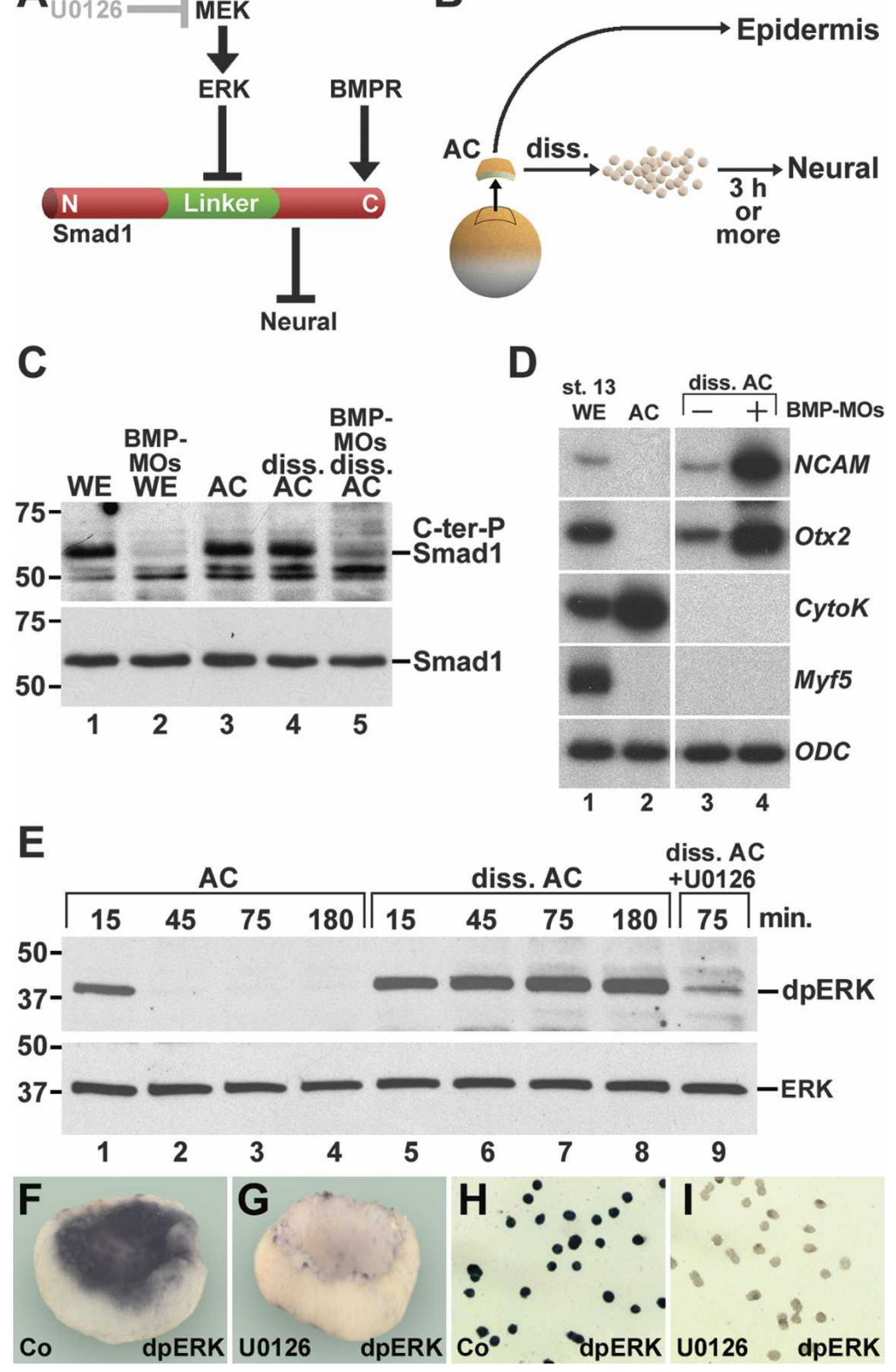

Figure 1. Cell dissociation does not cause BMP depletion by dilution, but rather triggers sustained ERK/MAPK activation in Xenopus ectodermal cells. $(A)$ Signaling pathway integration at the level of Smad1. $(B)$ Default neural induction in dissociated animal caps $(\mathrm{AC})$ cells. $(C)$ Western blot assay using anti-C-terminal-phosphoSmad1 (C-ter-P-Smad1) antibody in animal cap cells microinjected with Smad1 mRNA; note that BMPR signaling is not affected by cell dissociation. (WE) Whole embryo; (diss. AC) dissociated animal caps. (D) RT-PCR of neural (NCAM, Otx2), mesodermal (Myf5), and loading control $(O D C)$ markers, showing a great increase of neural differentiation when $\mathrm{Bmp} 2, \mathrm{Bmp} 4$, and $\mathrm{Bmp} 7$ are inhibited with specific MOs. (E) Sustained ERK activation revealed by anti-diphospho-ERK (dpERK) antibody in dissociated AC cells. A general ERK antibody serves as loading control. $(F, G)$ Activation of dpERK in a control animal explant $15 \mathrm{~min}$ after excision and its inhibition by addition of the MEK inhibitor U0126 at $40 \mu \mathrm{M}$. (H,I) Activation of dpERK in all cells 75 min after dissociation, and its dependence on MEK.

are dispersed by removing $\mathrm{Ca}^{2+}$ and $\mathrm{Mg}^{2+}$ for three or more hours neural differentiation ensues (Fig. 1B). This default neural induction is believed to be caused by the diffusion and dilution of endogenous BMPs, but this proposition has not been tested directly. To test whether
BMP signals are down-regulated in dissociated animal cap cells, we examined the level of endogenous BMP receptor (BMPR) signaling (Fig. 1A) on the transcription factor Smadl using a C-terminal phospho-specific antibody (Persson et al. 1998). Surprisingly, the same levels of Smad1 C-terminal phosphorylation were detected in intact or dissociated animal caps (Fig. 1C, cf. lanes 3 and 4).

A second line of evidence indicating that BMPs continue to signal in dissociated animal caps was provided by knock-down of endogenous BMP ligands. In the course of studies on the requirement of anti-BMP signals in neural induction, we designed and characterized antisense morpholino oligos (BMP-MOs) that inhibit specifically the activity of BMP2, BMP4, and BMP7 (Fig. 1C, lanes 2,5; B. Reversade, H. Kuroda, H. Lee, A. Mays, and E.M. De Robertis, in prep.). RT-PCR analyses using BMPMOs showed that endogenous BMP ligands continue to signal in dissociated ectoderm (Fig. 1D, cf. lanes 3 and 4). As expected, uninjected animal cap explants expressed the epidermal-specific marker Cytokeratin in the absence of the mesoderm marker Myf5. After dissociation, these cells gained expression of the pan-neural marker NCAM and the anterior gene Otx2, and lost Cytokeratin expression (Fig. 1D, lanes 2,3). Remarkably, coinjection of anti-BMP morpholinos caused a large increase in neural differentiation in dissociated cells (Fig. 1D, lane 4). This indicates that although dissociated cells lost Cytokeratin expression, they had not yet reached their full neural potential. We conclude that, contrary to current belief, autocrine signaling by endogenous BMP proteins continues to take place, at the same levels as in intact animal cap explants, in dissociated Xenopus ectoderm undergoing neuralization.

\section{Cell dissociation causes sustained MAPK activation}

We next investigated whether activation of Ras/MAPK, through the molecular mechanism shown in Figure 1A, might provide an explanation for how lowering of Smadl activity could be achieved in the presence of BMPR signals in dissociated cells. We used a diphospho-specific ERK antibody (dpERK) that only recognizes the active form of the enzyme, to ask whether endogenous ERK signaling was activated by cell dissociation. Surgical excision of the animal cap was sufficient to phosphorylate ERK after $15 \mathrm{~min}$, but this activation was transient and undetectable in whole caps after $45 \mathrm{~min}$ in culture (Fig. 1E, lanes 1-4). Remarkably, cell dissociation caused sustained activation of ERK for at least $3 \mathrm{~h}$ in culture (Fig. 1E, lanes 5-8). Immunocytochemical staining showed that ERK was phosphorylated in cells neighboring the healing animal cap wound 15 min after excision (Fig. 1F). We note that this is the same region previously found to give rise to neural tissue in newt animal 
cap explants in which wound healing was delayed by sub-optimal saline solutions (Holtfreter 1944). ERK diphosphorylation is mediated by MEK (for MAPK/ERK kinase), which can be inhibited by the specific chemical inhibitor U0126 (Fig. 1A) in the micromolar range (Fig. 1E, lane 9). U0126 blocked both the transient ERK activation (Fig. 1F,G) in animal caps, and the sustained dpERK signal seen in dissociated cells (Fig. 1H,I). Interestingly, immunocytochemistry (see Materials and Methods) showed that after dispersal all ectodermal cells were strongly dpERK positive (Fig. 1H). We conclude that cell dissociation causes a sustained activation of the MEK/ERK pathway in Xenopus ectoderm.

\section{Ras/MAPK mediates neuralization}

We next asked whether MEK/ERK activation was required for default neural induction. As shown in Figure 2A, control animal cap cells dissociated for $5 \mathrm{~h}$ and then

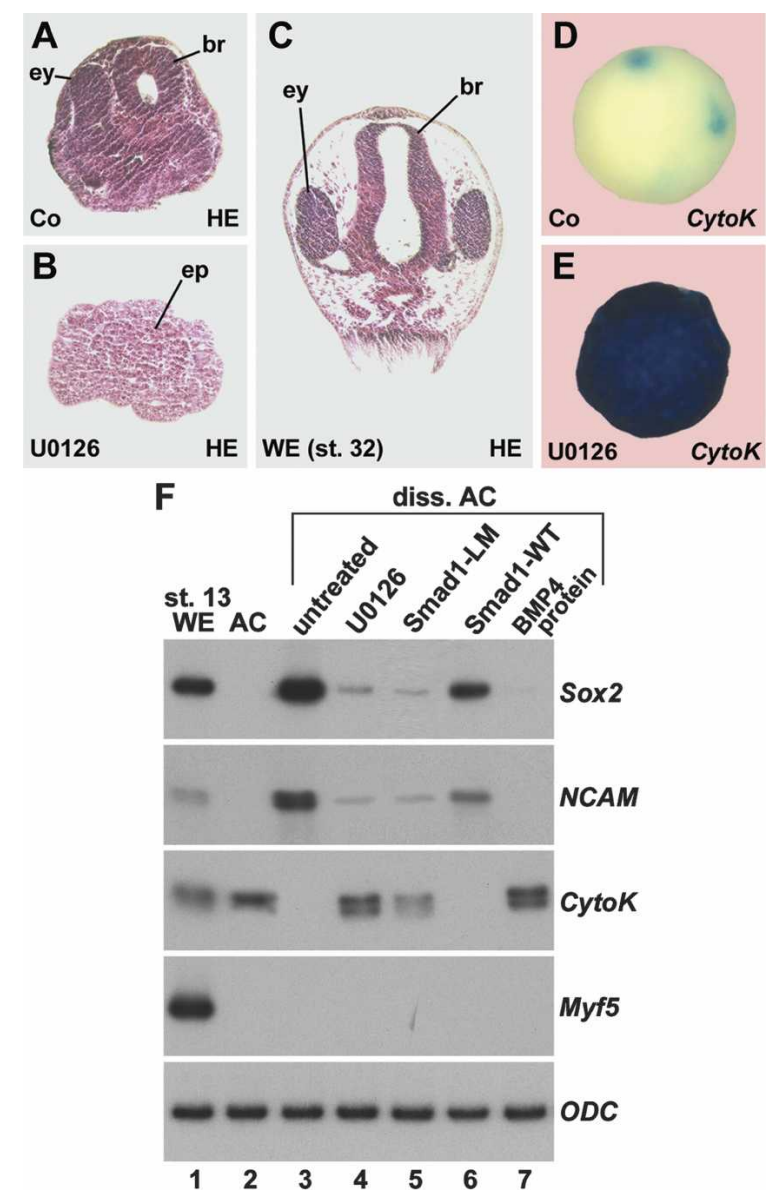

Figure 2. Histological sections, whole-mount in situ hybridizations, and RT-PCR analyses showing that inhibition of ERK blocks neural induction in dissociated animal cap cells. (A) Reaggregate from control $(\mathrm{Co})$ untreated cells dissociated for $5 \mathrm{~h}$, showing brain structures. $(B)$ Reaggregate from U0126-treated cells differentiated into epidermis. (C) Head region of sibling intact stage 32 embryo (Sive et al. 2000). (ey) Eye-like structure; (br) brain; (ep) epidermis. (D) Control reaggregates with low-Cytokeratin (CytoK) by in situ hybridization. (E) Strong expression of CytoK in reaggregate treated with U0126. (F) RT-PCR analysis of dissociated AC cells at stage 13 . Pan-neural marker (Sox2, NCAM) expression was inhibited and epidermal CytoK was induced by U0126 treatment, Smad-LM (but not Smad1-WT) mRNA injection, and $50 \mathrm{ng} / \mathrm{mL}$ (2 nM) BMP4 protein. allowed to reaggregate by addition of $\mathrm{Ca}^{2+}$ and $\mathrm{Mg}^{2+}$ differentiated into histotypic brain after $2 \mathrm{~d}$ in culture. Addition of the MEK inhibitor U0126 to the culture medium during dissociation blocked neural differentiation, causing the histological and molecular differentiation of epidermal tissue instead (Fig. 2B,D,E). In RT-PCR analyses carried out at early neurula (stage 13), cell dissociation eliminated Cytokeratin expression and induced expression of the pan-neural markers Sox 2 and NCAM (Fig. $2 F$, lanes 2,3). Addition of U0126 inhibited neural differentiation in dissociated cells and restored epidermal fate (Fig. 2F, lane 4). The MEK inhibitor was effective even if added $75 \mathrm{~min}$ after the initial dissociation (Supplementary Fig. 1A), indicating that its effect on neural differentiation was not dependent on the transient ERK activation caused by animal cap excision, but rather on the sustained activation described here for dissociated cells (Fig. 1E). The effect of U0126 on neural differentiation was specific for the ERK pathway (Supplementary Fig. 1B). The results indicate that MEK/ERK activation is required for default neural induction in dissociated Xenopus ectodermal cells; when ERK activation is prevented, dissociated cells develop as epidermis instead.

\section{MAPK-resistant Smad1 inhibits neuralization}

We next investigated whether phosphorylation of the linker Smad1 MAPK sites (Fig. 1A) was involved in the choice between epidermis and neural tissue, by comparing the effects of wild-type (WT) and linker mutant (LM) human Smad1 mRNA. The LM-Smad1 mutant has four serine-to-alanine substitutions at conserved PXSP sites that eliminate MAPK phosphorylation (Kretzschmar et al. 1997; Pera et al. 2003). Microinjection of this MAPKinsensitive LM-Smad1 mRNA strongly inhibited Sox2 and NCAM expression and restored epidermal (Cytokeratin-positive) differentiation of dissociated ectodermal cells (Fig. 2F, lane 5), whereas WT-Smad1 mRNA at the same concentration failed to block neuralization or cause epidermal differentiation (Fig. 2F, lane 6). Addition of recombinant BMP4 protein to dissociated ectoderm (Wilson and Hemmati-Brivanlou 1995) blocked neural induction and restored epidermal differentiation (Fig. 2F, lane 7). Exogenous BMP4 addition did not affect ERK activation, but caused a large increase in reserve Smad transcriptional activity detected by a BMP response element (BRE) reporter gene in animal cap (Supplementary Fig. 2). Thus, although endogenous levels of Smad1 activity in Xenopus animal caps are sufficient to cause epidermal differentiation, a large reserve pool of inactive BMP Smads exists. This spare capacity for additional $\mathrm{BMP}$ response explains why the addition of excess BMP4 protein restores epidermal differentiation to dissociated animal cap cells. The antineural effects of Smad1 linker mutants indicate that the inhibitory linker phosphorylation of Smad1 by ERK/MAPK plays a critical role in neural induction by cell dissociation.

\section{Activation of the Ras/MAPK pathway}

ERK activation is a late step in the Ras/MAPK signal transduction pathway regulated by RTKs (Fig. 3A). To investigate at which level cell dissociation activates the Ras/MAPK pathway we used, in addition to the MEK chemical inhibitor U0126, a dominant-negative form of Ras (Ribisi et al. 2000) and Xenopus Sprouty2 mRNA. 


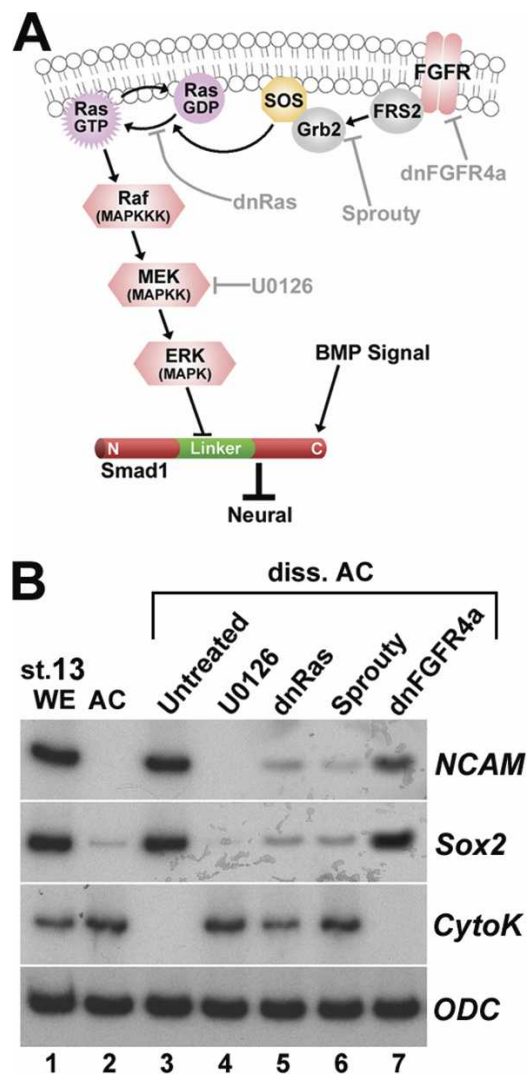

Figure 3. Dissociation activates much of the Ras/MAPK pathway. (A) Diagram of ERK pathway components. Dimerized FGF receptors (FGFR) become phosphorylated and recruit the Grb2-SOS complex via FGFR substrate protein 2 (FRS2). SOS activates Ras by exchanging GDP for GTP, allowing Ras to bind to and activate Raf (MAPKKK), which in turn activates MEK (MAPKK), and finally ERK (MAPK). (B) RT-PCR analysis of dissociated AC cells treated with U0126 or derived from dn-Ras, Xsprouty2, or dnFGFR4a mRNAinjected embryos. Inhibitors of the Ras/MAPK pathway, except for dnFGFR4a, blocked neural induction by cell dissociation, causing epidermal differentiation. The amount of $d n F G F R 4 a$ mRNA (50 pg/ blastomere at the four-cell stage) was sixfold less than that used by other authors (Hongo et al. 1999), as higher concentrations were toxic to the embryos.

Sprouty2 is a phosphoprotein that binds to the Grb2 adaptor (Nutt et al. 2001; Hanafusa et al. 2002), inhibiting the pathway just downstream of RTKs (Fig. 3A). All three inhibitors were able to block neural and restore epidermal markers in dissociated cells (Fig. 3B, lanes 3-6). Dominant-negative FGF receptor-4a (dnFGFR4a mRNA) (Hongo et al. 1999) only slightly inhibited neuralization and was unable to cause epidermal differentiation (Fig. 3B, lane 7), suggesting that Ras/MAPK activation in dissociated cells might involve other RTKs or be ligand-independent. We conclude that most of the Ras/ MAPK pathway, from Grb2 on down, is activated by cell dispersal.

\section{Cell dissociation phosphorylates endogenous Smad1}

To determine whether Smad1 itself is phosphorylated in dissociated Xenopus ectodermal cells, a phospho-specific antibody directed against a Smad1 MAPK site in the linker region was generated. Four conserved PXSP MAPK phosphorylation sites exist in Xenopus and hu- man Smad1; the antibody targeted the most C-terminal site in the linker region. Western blots of cell lysates showed that sustained linker phosphorylation of endogenous Xenopus Smad1 was, indeed, elicited by cell dispersal (Fig. 4A, lanes 1-8). Smad1 linker phosphorylation correlated with the time course of ERK activation (Fig. $1 \mathrm{E})$ and could be blocked by inhibiting MEK/ERK activity with U0126 (Fig. 4A, lane 9). These experiments on Smad1 linker phosphorylation reflect in vivo protein levels and did not involve overexpression of Smad1. We conclude that an inhibitory site on the endogenous Smad1 transcription factor becomes phosphorylated when Xenopus animal cap cells are dissociated.

\section{Choosing between neural and epidermal fates}

The default neural induction model has provided a very important paradigm for understanding how neural tissue is induced in Xenopus (Muñoz-Sanjuán and Brivanlou 2002). In this model, BMP signaling in the ectoderm plays a critical role in the choice between two alternative fates, epidermis or neural tissue (Harland 2000; De Robertis and Kuroda 2004). Dissociation of ectodermal cells induces anterior neural tissue and was believed to act through the dilution of endogenous BMPs, which would diffuse into the culture medium. Here we tested this proposal and found that autocrine BMP signals continue to function in dissociated cells at the same levels as those of animal cap explants that develop into epidermis.

In the dissociated animal cap system, anterior neural

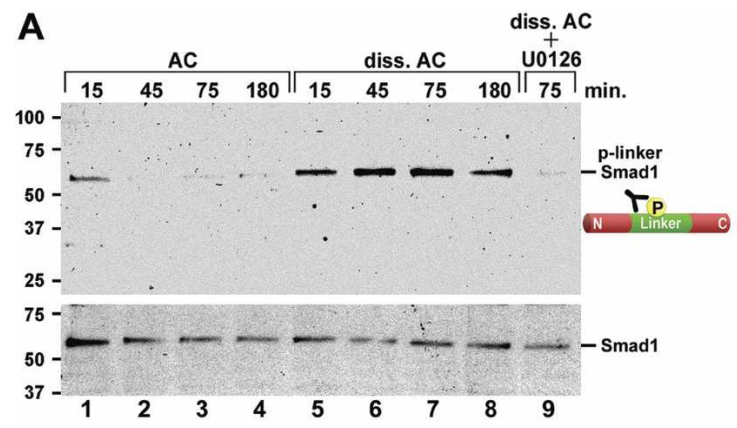

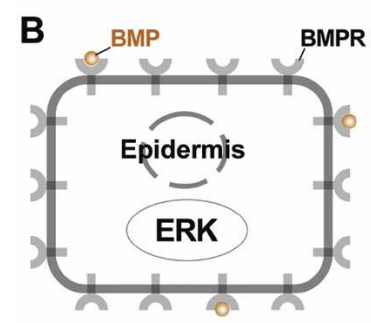

AC

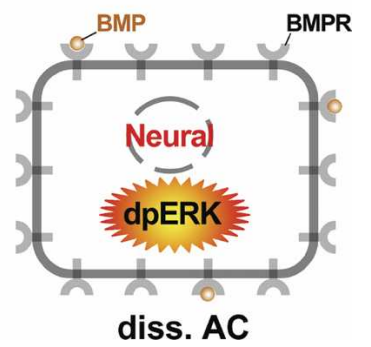

diss. AC
Figure 4. Cell dissociation causes linker-specific phosphorylation of Smad1 in Xenopus ectoderm. (A) Western blot time course using a linker-specific phospho-Smadl antibody that reacts with endogenous normal levels of Smad1. Cell dissociation induced sustained linker phosphorylation of Smad1, which was blocked by the MEK inhibitor U0126. A general Smad1 antibody serves as loading control. (B) Model for neural induction in dissociated AC cells. Ectodermal BMPs signal in autocrine fashion, but in dissociated cells their effect is counterbalanced by activation of the Ras/MAPK pathway, which causes an inhibitory phosphorylation in Smad1, lowering its activity. 
differentiation is entirely dependent on the activation of the Ras/MAPK pathway (Fig. 4B). This was shown by inhibition of MEK/ERK pathway components (by Sprouty2, dn-Ras, or U0126) or injection of mutant forms of Smad1 resistant to phosphorylation by MAPK, which inhibit neutralization and result in epidermal differentiation. Injection of $d n F G F R 4 a$ mRNA only slightly inhibited neural differentiation in our study, although strong inhibitory effects for anterior neural differentiation have been noted by others in Xenopus embryos (Hongo et al. 1999; Delaune et al. 2005). Low levels of FGF signaling are sufficient for anterior neural induction (Delaune et al. 2005); perhaps the amount of $\operatorname{dnFGFR4a}$ mRNA injected was insufficient to block FGF signaling. Another possibility is that many other RTKs for FGF, IGF, and other growth factors exist on surface of embryonic cells. The molecular mechanism by which a sustained activation of Ras/MAPK is induced by cell dissociation is unknown. It could involve, for example, the activation of multiple RTKs by increasing the rate of dimerization of these receptors in the cell membrane. Transient versus sustained activation of Ras/MAPK is known to cause distinct phenotypic effects in other systems; for example, in cultured pheochromocytoma PC12 cells EGF causes transient activation of Ras/MAPK and cell proliferation, while NGF causes sustained activation and neuronal differentiation (Marshall 1995).

Cell dissociation during the late blastula stage induces neuralization of ectodermal cells in Xenopus. However, work in the chick has suggested that BMP inhibition is required only as a late step during gastrulation (Linker and Stern 2004). The situation appears to be different in Xenopus embryos, in which injection of multiple BMPMOs or dnBMPRs can greatly increase neural marker expression (Yamamoto et al. 2001; B. Reversade and E.M. De Robertis, in prep.). In addition, the effects on neural differentiation of manipulating the BMP and FGF pathways are maximal at pre-gastrula stages in Xenopus (Delaune et al. 2005; Wawersik et al. 2005). This timing correlates with the observation that blastula cells on the dorsal side of the embryo, where the CNS will form, have high ERK and low BMPR signaling (Schohl and Fagotto 2002). The early BMP inhibition in the Xenopus blastula is achieved through transcriptional down-regulation of BMP4 and the expression of secreted BMP antagonists, such as Chordin and Noggin, in the future CNS by the action of an early $\beta$-catenin signal (Baker et al. 1999; Kuroda et al. 2004). The second critical step, which is the principal cause of neural differentiation in dissociated cells, is the activation of Ras/MAPK. Because endogenous BMP signals are still active in animal cap cells after dissociation (Fig. 1C,D), this system has an absolute requirement for sustained Ras/MAPK activity in order to attain the very low levels of endogenous $\mathrm{BMP} / \mathrm{Smad} 1$ signals required for neural differentiation. We conclude that anterior neural differentiation in Xenopus ectoderm results from the balanced integration of MAPK and BMPR signals at the level of Smad (Fig. 1A).

Classically, neural induction is considered the primary embryonic induction (Spemann 1938). As such, it has been the subject of intense investigation since it was discovered in 1924 that Spemann's organizer could induce neural tissue. An unresolved mystery in neural induction research, dating from the 1930s, is why dead organizer tissue and many heterologous substances such as fatty acids, sterols, methylene blue, and even sand particles were able to induce neural differentiation in newt embryonic ectoderm (Spemann 1938; Holtfreter and Hamburger 1955; De Robertis and Kuroda 2004). In future, it will be interesting to reinvestigate these observations in light of the essential role played by Ras/MAPK activation in default neural differentiation.

\section{Materials and methods}

Embryo manipulations

Xenopus laevis embryos were obtained by in vitro fertilization (Sive et al. 2000). AC cell dissociations were performed in $\mathrm{Ca}^{2+}, \mathrm{Mg}^{2+}$ free $1 \times$ Steinberg's solution (CMFSS: $58 \mathrm{mM} \mathrm{NaCl}, 0.67 \mathrm{mM} \mathrm{KCl}, 4.6 \mathrm{mM}$ Tris- $\mathrm{HCl}$ at $\mathrm{pH} 7.4,100 \mathrm{mg} / \mathrm{L}$ kanamycin) containing $0.1 \%$ Bovine serum albumin (BSA) at stage $9\left(7 \mathrm{~h}\right.$ after fertilization at $\left.22^{\circ} \mathrm{C}\right)$. The outer layer of cells was discarded, and the inner layer disaggregated into a single-cell suspension by gentle pipetting. All steps were carried out in $35 \times 10-\mathrm{mm}$ plastic plates (Fisher) coated with 6\% Poly (2-hydroxyethyl methacrylate) in ethanol (Polysciences) and allowed to dry for $30 \mathrm{~min}$. For cell reaggregations, cells from 10 explants were transferred $5 \mathrm{~h}$ after dissociation into $1 \times$ Steinberg's solution (SS) containing $0.83 \mathrm{mM} \mathrm{MgSO}_{4}$ and $0.34 \mathrm{mM}$ $\mathrm{Ca}\left(\mathrm{NO}_{3}\right)_{2}$ in $1.5 \mathrm{~mL}$ of NoStick Hydrophobic Microtubes (GENEMATE), centrifuged at $1000 \mathrm{rpm}$ for 10-15 sec; then fresh SS was added and the cells were cultured until sibling embryos reached stage 14 for in situ hybridization and stage 32 for histological assays. Hematoxylin solution (Gill's formulation \#3, Fisher) and eosin solution containing $0.2 \%$ eosin $\mathrm{Y}$ (Sigma) in $70 \%$ ethanol containing $0.02 \%$ acetic acid were used for histological staining. RT-PCR conditions and primers, as well as the protocol for whole-mount in situ hybridization, are described at http:// www.hhmi.ucla.edu/derobertis/index.html.

\section{RNA and morpholino injections}

To generate synthetic mRNAs, plasmids pCS2-smad1-WT, pCS2-smad1$L M$, pCS2-Xsprouty2, and pCS2-dnFGFR4a were linearized with NotI and transcribed with SP6 RNA polymerase, and pSP64T-dnRas with EcoRI and SP6 RNA polymerase (Hongo et al. 1999; Pera et al. 2003). After initial titration, the doses of mRNA were microinjected into each blastomere at the four-cell stage: $50 \mathrm{pg}$ for human Smad1-WT, $50 \mathrm{pg}$ for human Smad1-LM, $500 \mathrm{pg}$ for Sprouty2, $50 \mathrm{pg}$ for $d n-F G F R 4 a$, and $250 \mathrm{pg}$ for dnRas mRNAs. The 25-bp morpholino antisense oligomers for Bmp2, Bmp4, and Bmp7 targeted regions lacking mismatches with any of the allelic forms in the Xenopus EST database were obtained from Gene Tools, LLC and analyzed for biochemical and biological activity (B. Reversade, H. Kuroda, H. Lee, A. Mays, and E.M. De Robertis, in prep.). They consist of the following sequences: Bmp2-MO, 5'-GATCCCAGCGACCATTGTCAACCTG-3'; Bmp4-MO, 5'-CAGCATTCGGT TACCAGGAATCATG-3'; Bmp7-MO, 5'-TTACTGTCAAAGCATTCA TTTTGTC-3'. Control morpholinos of randomized sequence were without effect. Morpholinos were resuspended in sterile water to a concentration of $1 \mathrm{mM}$ each, then further diluted to give a working solution of $0.25 \mathrm{mM}$ (Bmp2-MO:Bmp4-MO:Bmp7-MO: $\mathrm{H}_{2} \mathrm{O}=1: 1: 1: 1$ ), and $2 \mathrm{~nL}$ was injected into each blastomere at the four-cell stage.

\section{Western blots}

Explant or cell lysates were prepared in PhosphoSafe Extraction Buffer (Novagen), lipids were removed by extracting once with an equal volume of 1,1,2-trichloro-1,2,2-trifluoroethane (Kodak), and proteins were separated by $4 \%-15 \%$ gradient SDS-PAGE gels (Bio-Rad). Western blots were performed using polyclonal rabbit antibodies against ERK1/2 (1:1000; Cell Signaling), Smad1 (1:1000; Upstate), and C-terminal phospho-Smad1 (1:4000; kind gift of C. Heldin, Ludwig Institute, Uppsala, Sweden) and monoclonal mouse antibody against diphospho-ERK1/2 (anti-dpERK-YT antibody, 1:1000; Sigma). To detect Smad1 C-terminal phosphorylation, embryos injected with Smad1-WT mRNA (500 pg) were used. The rabbit polyclonal antibody against phospho-linker Smad-1 was prepared by Covance Research Products and affinity-purified over a column of SSDPGS( $\left.\mathrm{PO}_{3}\right)$ PFQMPADT (Princeton BioMolecules Corporation) after negative selection with the unphosphorylated peptide. The antibody stains phospho-Smad-1 specifically in Western blots at 1:200,000 dilution (L. Fuentealba, A. Ikeda, and E.M. De Robertis, in prep.). Unphosphorylated peptide (6 nM) was added as a competitor. 


\section{Immunostaining}

Dissociated cells were allowed to attach for $1 \mathrm{~min}$ to uncoated plastic tissue culture dishes in CMFSS and fixed with MEMFA for $2 \mathrm{~h}$ at room temperature (Sive et al. 2000), washed with PBS, refixed (Christen and Slack 1999) with $0.1 \mathrm{M} \mathrm{K}_{2} \mathrm{Cr}_{2} \mathrm{O}_{7}$ in PBS for $1 \mathrm{~h}$, washed three times with PBS for $5 \mathrm{~min}$, dehydrated into methanol, treated with $5 \%$ hydrogen peroxide in methanol for $1 \mathrm{~h}$, and washed twice with methanol for $5 \mathrm{~min}$; the animal caps were stored at $-20^{\circ} \mathrm{C}$ until used. Samples were rehydrated into PBS, washed three times with PBS for $10 \mathrm{~min}$, incubated with BSA buffered Triton (BBT: $1 \%$ BSA and $0.1 \%$ Triton-X in PBS) buffer for $2 \mathrm{~h}$, incubated with 1:10,000 diluted anti-dpERK-YT antibody (Sigma) in BBT at $4^{\circ} \mathrm{C}$ overnight, washed four times with BBT at room temperature for $1 \mathrm{~h}$, treated with 1:1000 diluted anti-mouse IgG-conjugated to alkaline phosphatase (Novagen) in BBT at $4^{\circ} \mathrm{C}$ overnight, washed with BBT for $1 \mathrm{~h}$, washed with PBS-Tween (PBSw: 0.1\% Tween-20 in PBS) for $4 \mathrm{~h}$, washed twice with alkaline phosphatase buffer (APB: $0.1 \mathrm{M}$ Tris- $\mathrm{HCl}$ at $\mathrm{pH} 9.5,0.1 \mathrm{M} \mathrm{NaCl}, 50 \mathrm{mM} \mathrm{MgCl}_{2}$ ) for $5 \mathrm{~min}$, and stained with $\mathrm{BM}$ Purple substrate (Roche) diluted 1:10 in APB at $4^{\circ} \mathrm{C}$ overnight (Sive et al. 2000). The staining reaction was stopped by washing twice with PBS. All steps were performed in plastic dishes for dissociated AC cells and in $15 \times 45-\mathrm{mm}$ glass vials (Fisher) for AC explants.

\section{Acknowledgments}

We thank E. Amaya, H. Okamoto, and C. Heldin for materials; A. Mays and D. Greenberg for technical assistance; and S. Millard, X. Zhan, J. Kim, H. Lee, E. Eivers, and R. Nishinakamura for comments and advice on the manuscript. This work was supported by the NIH (R37 HD2150219). H.K. is an Associate and E.M.D.R. an Investigator of the Howard Hughes Medical Institute.

\section{References}

Baker, J.C., Beddington, R.S., and Harland, R.M. 1999. Wnt signaling in Xenopus embryos inhibits bmp4 expression and activates neural development. Genes \& Dev. 13: 3149-3159.

Barth, L.G. 1941. Neural differentiation without organizer. J. Exp. Zool. 87: $371-384$.

Christen, B. and Slack, J.M. 1999. Spatial response to fibroblast growth factor signalling in Xenopus embryos. Development 126: 119-125.

Delaune, E., Lemaire, P., and Kodjabachian, L. 2005. Neural induction in Xenopus requires early FGF signalling in addition to BMP inhibition. Development 132: 299-310.

De Robertis, E.M. and Kuroda, H. 2004. Dorsal-ventral patterning and neural induction in Xenopus embryos. Annu. Rev. Cell Dev. Biol. 20: 285-308.

Grunz, H. and Tacke, L. 1989. Neural differentiation of Xenopus laevis ectoderm takes place after disaggregation and delayed reaggregation without inducer. Cell Differ. Dev. 28: 211-217.

Hanafusa, H., Torii, S., Yasunaga, T., and Nishida, E. 2002. Sprouty1 and Sprouty2 provide a control mechanism for the Ras/MAPK signalling pathway. Nat. Cell Biol. 4: 850-858.

Harland, R. 2000. Neural induction. Curr. Opin. Genet. Dev. 10: 357362 .

Holtfreter, J. 1944. Neural differentiation of ectoderm through exposure to saline solution. J. Exp. Zool. 95: 307-343.

Holtfreter, J. and Hamburger, V. 1955. Amphibians. In Analysis of development (eds. B.H. Willier et al.), pp. 230-296. Haffner, New York.

Hongo, I., Kengaku, M., and Okamoto, H. 1999. FGF signaling and the anterior neural induction in Xenopus. Dev. Biol. 216: 561-581.

Kretzschmar, M., Doody, J., and Massagué, J. 1997. Opposing BMP and EGF signalling pathways converge on the TGF- $\beta$ family mediator Smad1. Nature 389: 618-622.

Kuroda, H., Wessely, O., and De Robertis, E.M. 2004. Neural induction in Xenopus: Requirement for ectodermal and endomesodermal signals via chordin, noggin, $\beta$-catenin and cerberus. PLoS Biol. 2: 623-634.

LaBonne, C. and Whitman, M. 1997. Localization of MAP kinase activity in early Xenopus embryos: Implications for endogenous FGF signaling. Dev. Biol. 183: 9-20.

Linker, C. and Stern, C.D. 2004. Neural induction requires BMP inhibition only as a late step, and involves signals other than FGF and Wnt antagonists. Development 131: 5671-5681.

Marshall, C.J. 1995. Specificity of receptor tyrosine kinase signaling:
Transient versus sustained extracellular signal-regulated kinase activation. Cell 80: 179-185.

Massagué, J. 2003. Integration of Smad and MAPK pathways: A link and a linker revisited. Genes \& Dev. 17: 2993-2997.

Muñoz-Sanjuán, I. and Brivanlou, A.H. 2002. Neural induction, the default model and embryonic stem cells. Nat. Rev. Neurosci. 3: $271-$ 280.

Nutt, S.L., Dingwell, K.S., Holt, C.E., and Amaya, E. 2001. Xenopus Sprouty2 inhibits FGF-mediated gastrulation movements but does not affect mesoderm induction and patterning. Genes \& Dev. 15: $1152-1166$.

Pera, E.M., Ikeda, A., Eivers, E., and De Robertis, E.M. 2003. Integration of IGF, FGF and anti-BMP signals via Smadl phosphorylation in neural induction. Genes \& Dev. 17: 3023-3028.

Persson, U., Izumi, H., Souchelnytskyi, S., Itoh, S., Grimsby, S., Engstrom, U., Heldin, C.H., Funa, K., and ten Dijke, P. 1998. The L45 loop in type I receptors for TGF- $\beta$ family members is a critical determinant in specifying Smad isoform activation. FEBS Lett. 434: 83-87.

Ribisi, S., Mariani, F.V., Aamar, E., Lamb, T.M., Frank, D., and Harland, R.M. 2000. Ras-mediated FGF signaling is required for the formation of posterior but not anterior neural tissue in Xenopus laevis. Dev. Biol. 227: 183-196.

Sato, S.M. and Sargent, T.D. 1989. Development of neural inducing capacity in dissociated Xenopus embryos. Dev. Biol. 134: 263-266.

Schohl, A. and Fagotto, F. 2002. $\beta$-Catenin, MAPK and Smad signaling during early Xenopus development. Development 129: 37-52.

Sive, H.L., Grainger, R.M., and Harland, R.M. 2000. Early development of Xenopus laevis: A laboratory manual. Cold Spring Harbor Laboratory Press, Cold Spring Harbor, NY.

Spemann, H. 1938. Embryonic development and induction. Yale University Press, New Haven, CT.

Stern, C.D. 2004. Neural induction. In Gastrulation, from cells to embryo (ed. C.D. Stern), pp. 419-432. Cold Spring Harbor Laboratory Press, Cold Spring Harbor, NY.

Wawersik, S., Evola, C., and Whitman, M. 2005. Conditional BMP inhibition in Xenopus reveals stage-specific roles for BMPs in neural and neural crest induction. Dev. Biol. 277: 425-442.

Wetzker, R. and Böhmer, D. 2003. Transactivation joins multiple tracks to the ERK/MAPK cascade. Nat. Rev. Mol. Cell Biol. 4: 651-657.

Wilson, S.I. and Edlund, T. 2001. Neural induction: Toward a unifying mechanism. Nat. Neurosci. 4: 1161-1168.

Wilson, P.A. and Hemmati-Brivanlou, A. 1995. Induction of epidermis and inhibition of neural fate by Bmp-4. Nature 376: 331-333.

Yamamoto, T.S., Takagi, C., Hyodo, A.C., and Ueno, N. 2001. Suppression of head formation by Xmsx-1 through the inhibition of intracellular nodal signaling. Development 128: 2769-2779. 


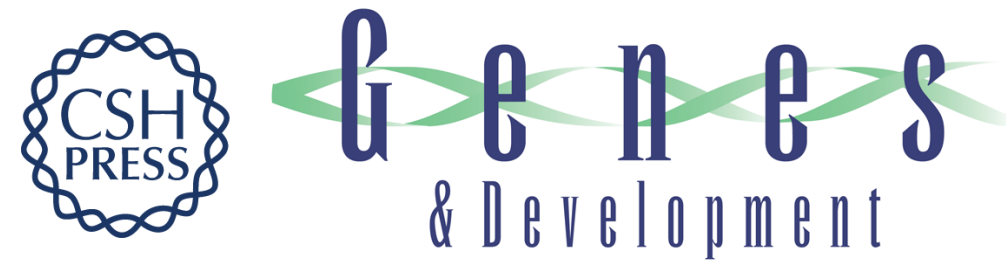

\section{Default neural induction: neuralization of dissociated Xenopus cells is mediated by Ras/MAPK activation}

Hiroki Kuroda, Luis Fuentealba, Atsushi Ikeda, et al.

Genes Dev. 2005, 19:

Access the most recent version at doi:10.1101/gad.1306605

\section{Supplemental http://genesdev.cshlp.org/content/suppl/2005/04/15/19.9.1022.DC1 Material}

References This article cites 24 articles, 8 of which can be accessed free at: http://genesdev.cshlp.org/content/19/9/1022.full.html\#ref-list-1

\section{License}

Email Alerting

Receive free email alerts when new articles cite this article - sign up in the box at the top Service

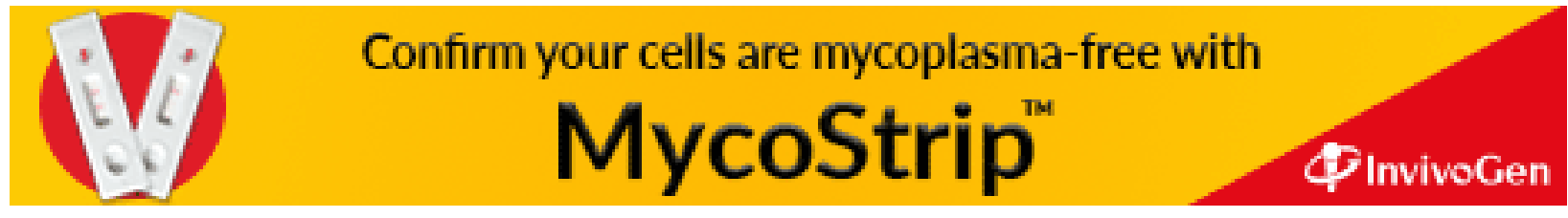

